\title{
Compost Plant Site Selection for Food Waste Using GIS Based Multicriteria Analysis
}

\author{
Sedat Yalcinkaya ${ }^{1, a, *}$, Sevin Uzer ${ }^{2, b}$, Hasan İhsan Kaleli ${ }^{2, c}$, Fatih Doğan $^{2, d}$, Mert Kayalık,e \\ ${ }^{1}$ Department of Civil Engineering, Faculty of Engineering and Architecture, Izmir Katip Celebi University, 35620, Izmir, Turkey \\ ${ }^{2}$ Department of Urban Regeneration, Graduate School of Natural and Applied Sciences, Izmir Katip Celebi University, 35620, Izmir, Turkey \\ ${ }^{3}$ Department of Geomatics Engineering, Graduate School of Natural and Applied Sciences, Izmir Katip Celebi University, 35620, Izmir, Turkey \\ *Corresponding author
}

\begin{tabular}{l|l}
\hline A R T I C L E I N F O & A B S T R A C T \\
\hline & Marketplace waste collection is one of the crucial services provided by the district municipalities in
\end{tabular}

Research Article

Turkey. A significant amount of food waste is periodically collected from marketplaces. However, an important opportunity for recycling and mitigation climate change is missed because these waste

Received : 09/08/2021

Accepted : 09/09/2021 are sent to landfills. Composting, one of the waste management technologies applied to organic waste to reduce greenhouse gas emissions and produce compost, is often preferred for the management of marketplace waste. This study aims to determine suitable locations for compost facilities to manage marketplace waste with the help of GIS considering economic, environmental, and topographic factors in Izmir, Turkey. There are 199 marketplaces in Izmir and each has at least one market a week. Each marketplace was weighted by means of population served by using location-allocation analysis since the amount of waste collected from the marketplaces is not

Keywords:

Compost

Food Waste

GIS

Land Suitability

Site Selection

known. First, an exclusion analysis was performed to remove limited use areas. Then, a preference analysis was performed. Factors affecting plant site selection process for composting marketplace waste, including marketplace locations and weights, were determined. Since all factors do not have equal importance, the analytical hierarchy process was used to determine weights for each factor based on their influence. The study area was spatially evaluated for each preference factor and a suitability map was created for each factor. Finally, a high-resolution final suitability map was obtained by combining each factor's suitability map along with their weights. Areas with a suitability index greater than $80 \%$ have been defined as suitable areas for compost facility installation. The results indicate that there are 323 potential locations suitable for compost facilities in Izmir.

\footnotetext{
a sedat.yalcinkaya@ikc.edu.tr c- hasanihsankaleli@gmail.com e@kayalikmert@gmail.com

(iD) https://orcid.org/0000-0003-3062-2698 (iD) https://orcid.org/0000-0002-7221-9234 (iD) https://orcid.org/0000-0002-1666-2215

b@sevinuzer@gmail.com d_fatih.dogan9696@gmail.com

D htps://orcid.org/0000-0002-0125-1384 iD https://orcid.org/0000-0003-0430-8443
}

\section{Introduction}

The world population is expected to be between 9.4 and 10.1 billion in 2050 (United Nations, 2019). Parallel to this increase, the global demand for food is predicted to be increased by $35-50 \%$ between 2012 and 2050 to feed the world population (Food and Agriculture Organization of the United Nations, 2018). As a result, food waste is expected to increase as well. Proper management of food waste is also seen as a way to contribute climate change mitigation by reducing greenhouse gas emissions. Food waste can be defined as the decline in the quantity or quality of food occurring from retail to the final consumption (Jenkins et al., 2016). Since food loss and waste have several impacts at the global level, Committee on World Food Security recommended the 'food use-not- waste' hierarchy to reduce food loss and waste (Food and Agriculture Organization of the United Nations, 2014). Composting, one of the steps in the hierarchy, is an important alternative for organic waste within the integrated solid waste management strategy that can be implemented to municipal solid waste (MSW) or separately collected food waste (Hocking, 2006). Determining the methodology and standardization for the use of products obtained from compost facilities as soil improver on degraded lands is one of the action plans for the prevention, reduction and management of food losses and waste in Turkey (Food and Agriculture Organization of the United Nations, 2020). 
MSW is a multidisciplinary activity that includes collection, transportation, processing, treatment, recycling, or disposal of waste materials (Das and Bhattacharyya, 2015; Höke and Yalcinkaya, 2021; Kutlu and Mutlu, 2021; Mutlu, 2021; Rada et al., 2013; Yalçınkaya, 2020). Collection and transportation of solid waste is the first step in the MSW system and causes significant transportation costs and exhaust gas emissions. For optimum planning, distance between the waste recycling, treatment and disposal facilities, and waste sources must be minimized. Since marketplaces are geographically dispersed, siting compost facilities becomes an important aspect of food waste management system. Many criteria play a role in the selection of compost facility location and most of them are spatially variable. Therefore, geographic information system (GIS) is utilized in site selection process. Since site selection is also a multi-criteria decision making (MCDM) process, MCDM methods; such as the Analytic Hierarchy Process (AHP), are often used (Saaty, 2002).

Most of the site selection studies in the MSW management system are on landfill siting. The traditional approach, by integrating AHP and GIS, has been applied in most studies for different study areas (Chabuk et al., 2017; Güler and Yomralıoğlu, 2017; Hazarika and Saikia, 2020; Kamdar et al., 2019; Khodaparast et al., 2018; Uncumusaoğlu and Mutlu, 2019; Kilicoglu et al., 2020; Kükrer and Mutlu, 2019; Mutlu, 2019; Randazzo et al., 2018; Tokatlı et.al., 2021; Tüdeş and Kumlu, 2017; Yalcinkaya, 2020a; Yalcinkaya and Kirtiloglu, 2021;). In the aforementioned studies, criteria are divided into the basic contexts, namely environmental, morphological and economic. For example; Barzehkar et al. (2019) determined the most suitable location for a MSW landfill by comparing fuzzy logic and boolean logic. Ecological and socioeconomic criteria were considered by using GIS and MCDM methods together. Also, Yildirim et al. (2018) used TOPSIS (Technique for Order Preference by Similarity to Ideal Solutions) technique and GIS to determine alternative locations for MSW landfills in Bursa, Turkey. Sadhasivam et al. (2020) applied GIS-based MCDM techniques to determine optimum landfill sites in Thiruverumbur taluk in Tiruchirappalli district, India. In addition, GIS and remote sensing techniques were used to process the geographic database in this study. In the end, a suitability index was created to identify candidate landfill sites. Chabuk et al. (2017) proposed an approach combining AHP and Simple Additive Weighting to obtain potential landfill sites.

While most of the site selection studies in MSW management have focused on landfill siting, some researchers have also focused on other waste management facilities. In the study carried out by Yalcinkaya and Kirtiloglu (2021) a model was developed based on fuzzy AHP and GIS to site an incineration plant in Izmir, Turkey. This study involved a pre-screening process to exclude unsuitable areas and a preference analysis to spatially scale the study are for each preference factor. Babalola (2018) used the weighted linear combination approach that MCDA applied for the procurement of suitability maps to site anaerobic digestion facilities for food and biodegradable waste. Khan et al. (2018) conducted a combined GIS and AHP method for siting waste conversion facilities including biofuel facilities, electricity facilities, composting, and anaerobic digestion facilities.

This study aims to determine suitable locations for compost facilities to manage marketplace waste with the help of GIS considering economic, environmental and topographic factors in Izmir, Turkey. So that marketplace waste can be recycled and greenhouse gas emissions from improper management and transportation of marketplace waste can be reduced. Economic, environmental, and topographic factors were evaluated spatially and the most suitable locations for compost facilities were determined by performing a GIS based MCDM approach.

\section{Materials and Methods}

The methodology of the study can be summarized as follows: Firstly, criteria and related factors were determined. Then, the weights of the marketplaces based on population served were determined. For this purpose, Location-Allocation analysis was carried out that reveals which marketplace serves which neighborhood and the number of the population served. In the continuation of the study, exclusion analysis was done by taking into account legal obligations and other studies. Later on, ten factors were weighted via AHP under the three main criteria. Then, preference analysis was performed to evaluate spatial suitability degree of each criterion. The final suitability map was produced by weighted summing each preference map based on their AHP weight.

\section{Study Area}

Izmir is the most developed city on the Aegean coast of Turkey. Izmir is located in the middle of the Aegean Region and around Izmir Bay. The territory of the province lies between $37^{\circ} 45^{\prime}-39^{\circ} 15^{\prime}$ north latitudes and $26^{\circ} 15^{\prime}$ $28^{\circ} 20^{\prime}$ east longitudes. Its area is approximately 12,000 $\mathrm{km}^{2}$. The population of Izmir is 4,394,694 people which makes it the 3rd most populous city in Turkey (Turkish Statistical Institute, 2021). The city has 30 districts and 1,295 neighborhoods. The location of the study area is presented in Figure 1.

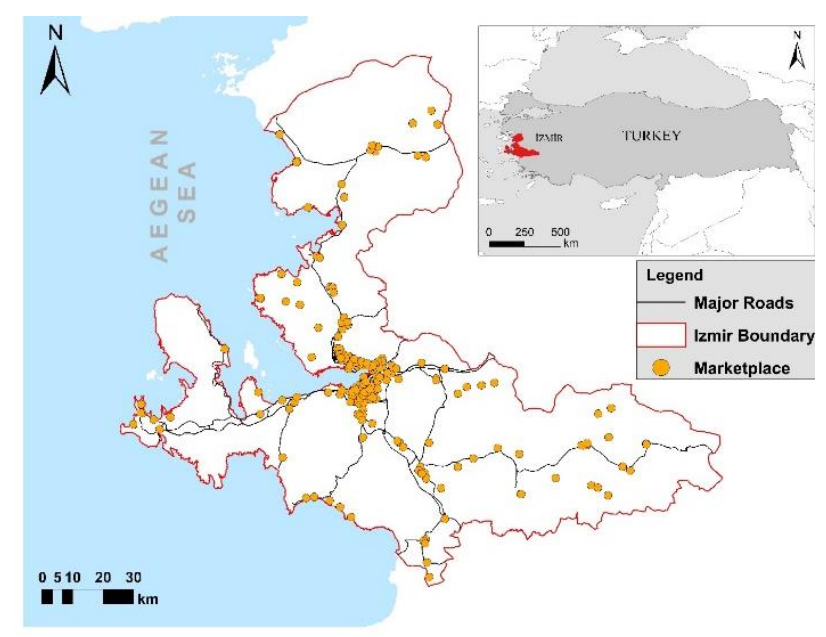

Figure 1. Map of the study area illustrating market areas, neighborhoods, and major roads. 


\section{Selection and Preparation of Criteria}

In the study, 10 factors based on 3 criteria were identified (Table 1). Resource availability factor, which is one of the economic criteria, reflects the availability of marketplace waste that will form raw materials for the compost plant. Distance to wastewater plants and agricultural lands were considered as economic factors since wastewater to be formed in the compost plant may require treatment and compost can be used as soil improver at agricultural lands. Distance to the major roads is also an important economic. Because the transportation possibilities of both the source to be used and the products to be formed depend on this factor. Distance to protected areas, touristic places, water bodies and settlements factors, which constitute the environmental criteria, have been determined considering the human and environmental helth, and aesthetics. Under the topography criteria, slope and surface area requirement were evaluated.

Table 1. Preference factors, rasterization techniques to drive factors, minimum and maximum values for transformation functions, and AHP weights

\begin{tabular}{|c|c|c|c|c|c|}
\hline Criteria & Factor & Rasterization & Min & Max & Weight \\
\hline \multirow{4}{*}{ Economic } & Resource availability & $\begin{array}{l}\text { Inverse Distance } \\
\text { Weighted }\end{array}$ & Min & $\operatorname{Max}$ & 0.26 \\
\hline & Distance to major roads & $\begin{array}{l}\text { Distance } \\
\text { Accumulation }\end{array}$ & $1000 \mathrm{~m}$ & $30 \mathrm{~m}$ & 0.14 \\
\hline & Distance to agricultural land & $\begin{array}{l}\text { Distance } \\
\text { Accumulation }\end{array}$ & $2000 \mathrm{~m}$ & $1000 \mathrm{~m}$ & 0.09 \\
\hline & $\begin{array}{l}\text { Distance to wastewater } \\
\text { treatment plants }\end{array}$ & $\begin{array}{l}\text { Distance } \\
\text { Accumulation }\end{array}$ & Max & Min & 0.06 \\
\hline \multirow{4}{*}{ Environmental } & Distance to water bodies & $\begin{array}{l}\text { Distance } \\
\text { Accumulation }\end{array}$ & $250 \mathrm{~m}$ & $\operatorname{Max}$ & 0.12 \\
\hline & Distance to protected areas & $\begin{array}{l}\text { Distance } \\
\text { Accumulation }\end{array}$ & $500 \mathrm{~m}$ & $\operatorname{Max}$ & 0.11 \\
\hline & Distance to touristic areas & $\begin{array}{l}\text { Distance } \\
\text { Accumulation }\end{array}$ & $500 \mathrm{~m}$ & $\operatorname{Max}$ & 0.06 \\
\hline & Distance to settlements & $\begin{array}{l}\text { Distance } \\
\text { Accumulation }\end{array}$ & $250 \mathrm{~m}$ & $\operatorname{Max}$ & 0.04 \\
\hline \multirow{2}{*}{ Topographic } & Slope & DEM to Slope & 15 degree & 0 degree & 0.09 \\
\hline & Surface area & Polygon to Raster & 1ha & $10 \mathrm{ha}$ & 0.03 \\
\hline
\end{tabular}

Table 2. Data types and sources used in the study.

\begin{tabular}{l|l}
\hline \multicolumn{1}{c}{ Data type } & \multicolumn{1}{c}{ Source } \\
\hline Digital elevation model & NASA SRTM \\
Administrative boundaries & General Directorate of Mapping \\
Population & Turkish Statistical Institute (2021) \\
Landuse & Ministry of Environment and Urban Planning \\
Road network & OpenStreetMap \\
Neighborhood locations & Generated with Google geocode API and crosschecked with up-to-date Ministry of \\
Marketplace locations & Interior neighborhood names list \\
\hline
\end{tabular}

Table 2 presents the data and sources used in the study. Marketplace locations and related neighborhood populations were taken as reference for the resource availability factor, slope was derived from digital elevation model obtained from the NASA SRTM, road network was built by using openstreetmap data, and landuse data was obtained from the Ministry of Environment and Urbanization in vector format. Major roads data includes Motorway, Motorway_link, Trunk, Trunk_link, Primary, Primary_link classes in OSM. water bodies data includes lakes, ponds, dams, and streams. Protected area and touristic areas factors were derived from the landuse data. Protected areas include special environmental protection zones, natural parks, culture-tourism protection, and development zones. Touristic areas factor includes tourism center, beach, and tourism facility areas.

\section{Location allocation analysis for weighting} marketplaces

The weighting marketplaces step was conducted to estimate the weight for each marketplace based on population served. Addresses of the marketplaces were obtained in table form from the Izmir Metropolitan Municipality. In addition, 2020 population data of the neighborhoods was downloaded from the Turkish Statistical Institute (2021). The goal of location-allocation analysis is to locate the facilities in a way that supplies the demand points most efficiently. A location-allocation analysis was conducted to determine which marketplace serves which neighborhood and how much of the neighborhood population. The 199 marketplaces were divided into two groups as urban (99) and rural (100). Two different location-allocation analyses, LA_urban and LA_rural, were performed for these two separated groups. 
In the LA_urban analysis, a maximum of 10 minutes driving time was chosen as the criterion, while in the LA_rural analysis, a maximum of 15 minutes driving time was chosen as the criterion. Maximize market share problem type was used in both analyses. 1,295 neighborhoods (demand points) were processed. 389 of them were assigned to urban marketplaces, and 497 neighborhoods were assigned to the rural marketplaces. 409 neighborhoods were not allocated to any marketplace within the given drivetime limits. Allocation of neighborhoods to the marketplaces is shown in Figure 2.

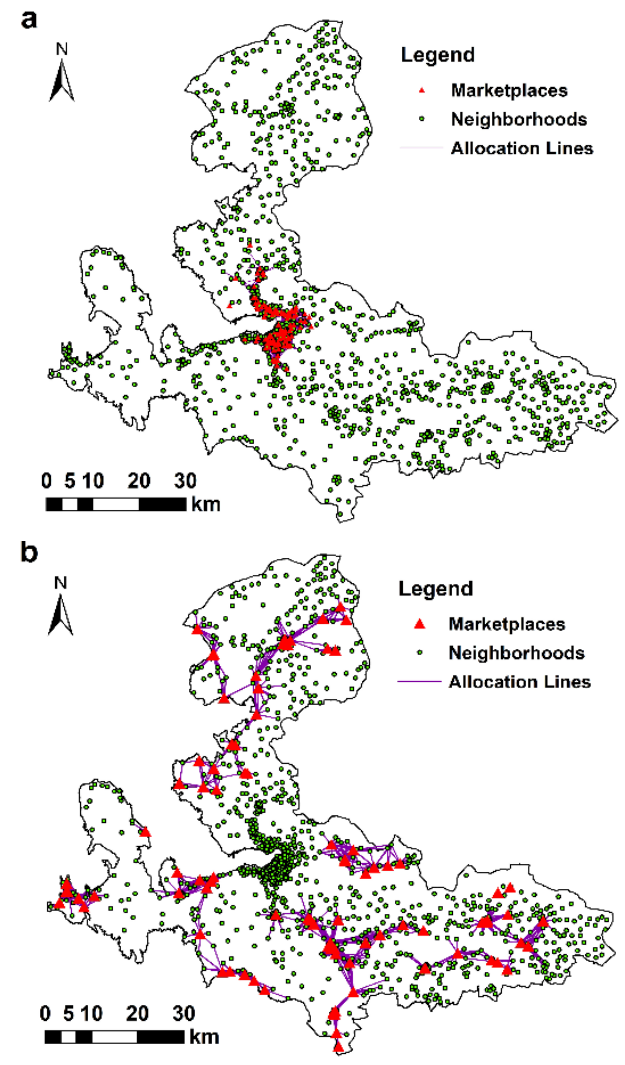

Figure 2. Allocation of neighborhoods to the a) urban marketplaces and b) rural marketplaces

\section{Exclusion Analysis}

Some areas should be excluded for compost plant siting. For this reason, exclusion analysis was carried out taking into account legally and technically limited use areas. Firstly, the areas to be excluded were determined (forest, industry and tourism regions, protected areas and prohibited military zones, etc.). The areas to be buffered within the excluded areas were determined as follows: 250 $\mathrm{m}$ buffer for settlements (Ministry of Environment and Urbanization, 2015), 10-30 m buffer for road network, 50$200 \mathrm{~m}$ buffer for water bodies, $500 \mathrm{~m}$ buffer for environmental protection areas (Sliz-Szkliniarz and Vogt, 2012; Sultana and Kumar, 2012). In the continuation of the study, the buffered areas were merged with the other unsuitable areas and excluded from the study area. The resulting area was defined as suitable.

\section{Preference Analysis}

The preference factors were compared among themselves according to the degree of importance and comparison matrices were created. While making this comparison, the criteria were scored according to the scoring table of Saaty (2002). According to the results obtained, final weight values were obtained for each criterion.

Each factor was derived from the base data in raster format to be used in suitability analysis. During this process, different rasterization methods were used for each factor (Table 1). Seven factors based on distance were rasterized by the distance accumulation method. For the resource availability factor, the marketplace demand weights obtained as a result of location-allocation were taken as a basis. These demand weights were rasterized by spreading over the entire study area using the inverse distance weighted interpolation method. The surface area factor was rasterized according to the polygon areas. Slope was produced using DEM in raster format.

Since the cell value units (meters, degrees, etc.) of the rasters produced for each factor are different, they cannot be used for suitability analysis. Proper functions, representing the suitability of a factor for siting compost plats were used to equalize each raster in a common scale. Thus, all rasters have been transformed between 1-10 by using linear functions with proper parameters (Table 1). For example, since proximity is taken as the basis for distance to major roads factor, the distance to give the maximum suitability value is 30 meters, while the distance to give the minimum suitability value is 1000 meters. Suitability value of 10 was assigned to areas 30 meters away, while suitability value of 1 was assigned to areas 1,000 meters away and above. It also scales areas between 30 and 1000 meters linearly and assigns intermediate values between 1 and 10 . In the rasterization process, rasters with a cell size of $5 \mathrm{~m}$, excluding the slope, were generated. Since there is no DEM data with sufficient resolution, a slope with a cell size of $30 \mathrm{~m}$ was generated.

\section{Suitability Analysis}

Firstly, all rasters produced for each factor were matched with AHP weights, and weighted summed to create the final suitability map in raster format with a cell size of $5 \mathrm{~m}$. Weighted Sum overlays several rasters, multiplying each by their given weight and summing them together. The resulting suitability map was normalized to a scale between 1 and 10 . Then, the regions with a suitability index value of 8 or more were separated and saved in vector format.

\section{Results and Discussion}

As a result of the exclusion analysis, an area of 7,153 $\mathrm{km}^{2}$ within the borders of the mainland of Izmir, which has a total area of $11,970 \mathrm{~km}^{2}$, has been remained. The excluded areas represent approximately $60 \%$ of the study area (Figure 3). Yalcinkaya and Kirtiloglu, (2021) excluded $97 \%$ of their study area for an incineration facility. It is estimated that the main reason for this difference is that agricultural lands were not excluded in the present study. Since the composts produced from organic wastes are used as fertilizer in the agricultural lands and also, agricultural lands can be evaluated as potential organic waste sources in the future, it is not restricted and proximity is preferred. 


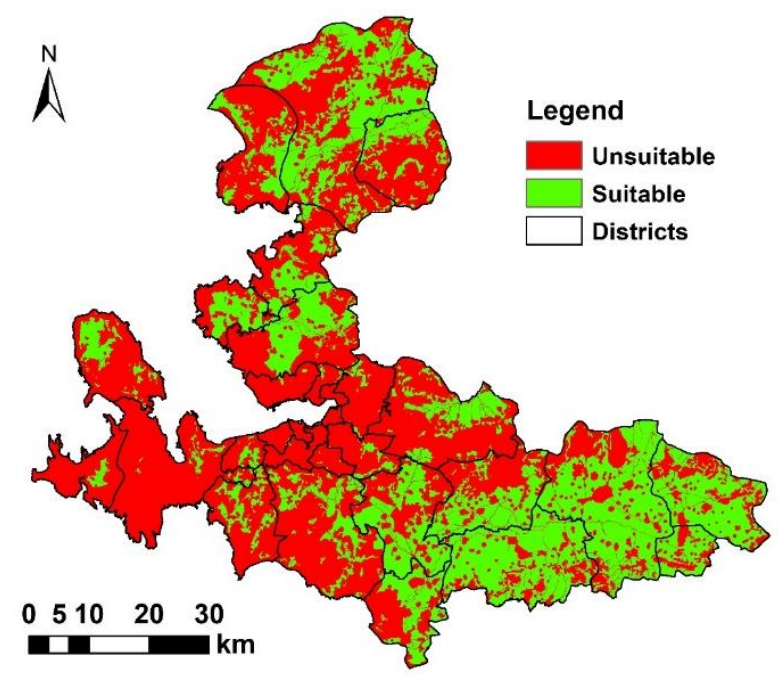

Figure 3. Excluded and suitable areas
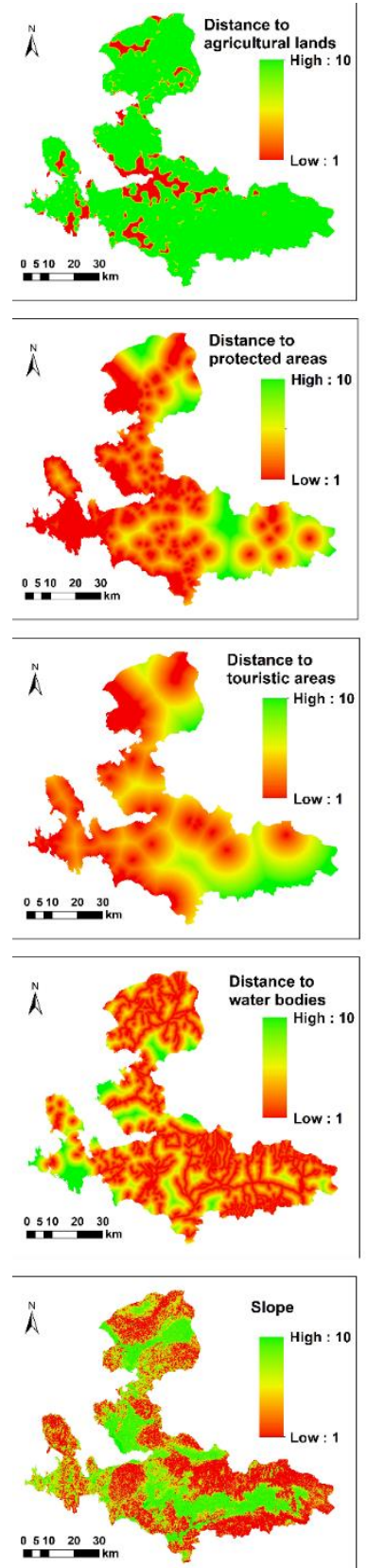

Figure 4. Transformed preference factors
Transformed preference factors were shown in Figure 4. Distance to water bodies, distance to protected areas, distance to settlements and distance to touristic places factors show a direct correlation between the distance and the degree of suitability, while there is an opposite relationship in the distance to major roads, distance to agricultural land and distance to wastewater treatment plants factors. Izmir Bay and its surroundings have scores for high resource availability due to high population density. Distance to major roads resulted as the most restricting factor, while distance to agricultural lands is the least. Distance to major roads, which is one of the economic factors, played a key role with the effect of having a narrow preferred area.

While determining the preferred factors and excluded area, it is aimed to provide an environmentally and economically sustainable management for marketplace waste. When the weights resulting from the AHP in Table 1 are examined, $12 \%$ of the total weight is composed of topographic criteria, 33\% environmental, and 55\% economic criteria. The dominance of economic sustainability is also reflected in the suitability result.

In Figure 5 blank areas are unsuitable areas. Areas with a suitable index of 3.23 represent the least suitable areas, and areas with 10 represent the most suitable areas. However, not every region with a high suitability index is a potential region for the location of a facility. In the literature, those who have a suitability index greater than or equal to eight $(\mathrm{SI} \geq 8$ ) were considered suitable (Sultana and Kumar, 2012; Yalcinkaya, 2020b). For this reason, cell clusters with a suitability index greater than 8 and also wide enough to meet the facility area requirement (1-10 ha) were converted into vector format. 323 potential points were determined to be suitable for composting in Izmir (Figure 6 ). Potential points were searched in cell clusters with $\mathrm{SI} \geq$ 8.5 and SI $\geq 9$, but they did not show a balanced distribution as in Figure 6. This study, which is the first to determine the suitable places for compost facilities in the city of Izmir, can guide the waste management authorities for environmentally and economically sustainable management of marketplace waste.

\section{Conclusion}

Site selection/land suitability analyses are complex problems. In this study, 323 potential locations were determined for compost facility siting problem with GISbased MCDM analysis. Marketplace waste are considered as the waste source, since they are periodically collected by separate waste collection trucks and sent to landfills in Izmir. As the number of preference factors increases, the sensitivity of the study increases and the area to be selected for the appropriate location narrows. In the following studies, vehicle routing problem analysis between the marketplaces and the potential compost facility sites (SI $\geq$ 8) can be conducted to reduce the alternatives. Besides, transportation distances, fuel consumptions, exhaust emissions, and facility capacities can be determined via vehicle routing problem analysis. However, average waste amounts data for each marketplace must be available. 


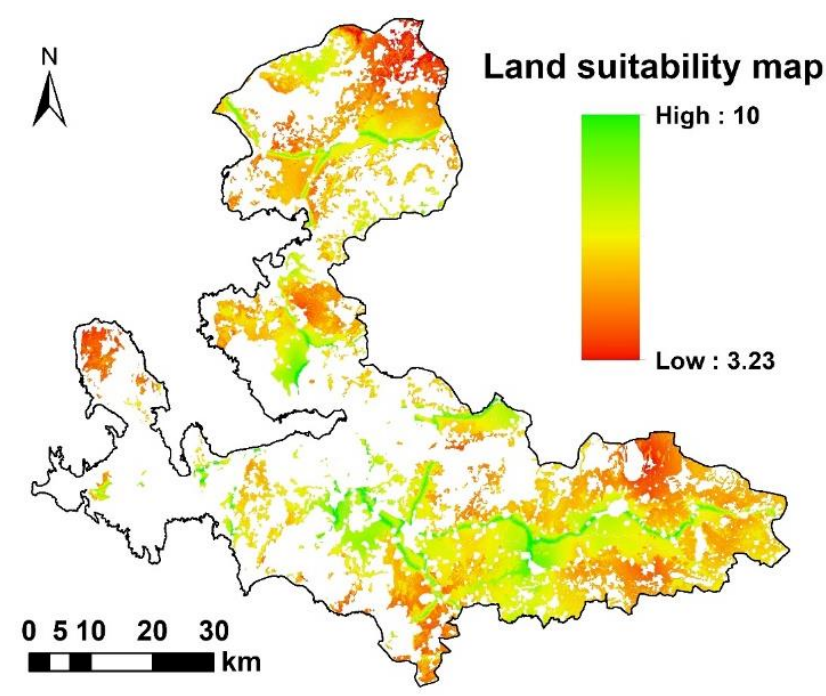

Figure 5. Land suitability map

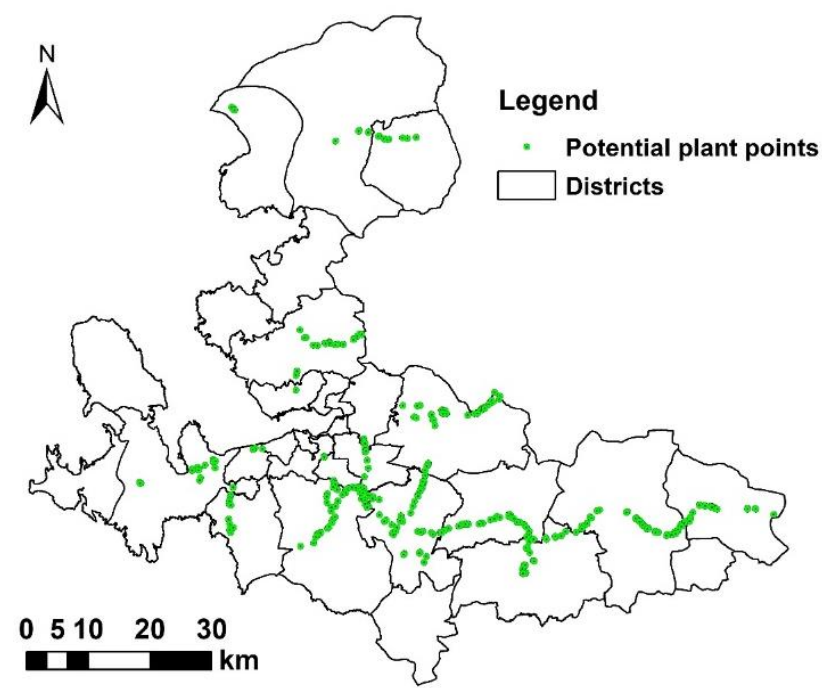

Figure 6. Suitable sites for compost facilities in Izmir

\section{References}

Babalola MA, 2018. Application of GIS-based multi-criteria decision technique in exploration of suitable site options for anaerobic digestion of food and biodegradable waste in Oita City, Japan. Environ. - MDPI, 5: 1-16. doi:10.3390/ environments5070077

Barzehkar M, Dinan NM, Mazaheri S, Tayebi RM, Brodie GI, 2019. Landfill site selection using GIS-based multi-criteria evaluation (case study: SaharKhiz Region located in Gilan Province in Iran). SN Appl. Sci., 1., DOI: https://doi.org/ 10.1007/s42452-019-1109-9

Chabuk AJ, Al-Ansari N, Hussain HM, Knutsson S, Pusch R, 2017. GIS-based assessment of combined AHP and SAW methods for selecting suitable sites for landfill in AlMusayiab Qadhaa, Babylon, Iraq. Environ. Earth Sci., 76., DOI: https://doi.org/10.1007/s12665-017-6524-x

Das S, Bhattacharyya BK, 2015. Optimization of municipal solid waste collection and transportation routes. Waste Manag., DOI: https://doi.org/10.1016/j.wasman.2015.06.033

Food and Agriculture Organization of the United Nations, 2020. Türkiye'nin Gıda Kayıpları ve İsrafinın Önlenmesi, Azaltılması ve Yönetimine ilişkin Ulusal Strateji Belgesi ve Eylem Planı. Available from: http://www.fao.org/ publications/card/fr/c/CB1074TR/ [Accessed 11 August 2021]
Food and Agriculture Organization of the United Nations, 2018. The future of food and agriculture - Alternative pathways to 2050. Available from: http://www.fao.org/3/CA1553EN/ ca1553en.pdf [Accessed 12 August 2021]

Güler D, Yomralığlu T, 2017. Alternative suitable landfill site selection using analytic hierarchy process and geographic information systems: a case study in Istanbul. Environ. Earth Sci., 76., DOI: https://doi.org/10.1007/s12665-017-7039-1

Hazarika R, Saikia A, 2020. Landfill site suitability analysis using AHP for solid waste management in the Guwahati Metropolitan Area, India. Arab. J. Geosci., 13., DOI: https://doi.org/10.1007/s12517-020-06156-2

Hocking MB, 1999. Solid waste, in: Environmental Geology., DOI: https://doi.org/10.1007/1-4020-4494-1_313

Höke MC, Yalcinkaya S, 2021. Municipal solid waste transfer station planning through vehicle routing problem-based scenario analysis. Waste Manag. Res., 39: 185-196. doi: $10.1177 / 0734242$ X20966643

Jenkins W, Tucker ME, Grim J, 2016. Routledge handbook of religion and ecology, Routledge Handbook of Religion and Ecology. ISBN 9781315764788

Kamdar I, Ali S, Bennui A, Techato K, Jutidamrongphan W, 2019. Municipal solid waste landfill siting using an integrated GIS-AHP approach: A case study from Songkhla, Thailand. Resour. Conserv. Recycl., 149: 220-235. doi: 10.1016/j.resconrec.2019.05.027

Khodaparast M, Rajabi AM, Edalat A, 2018. Municipal solid waste landfill siting by using GIS and analytical hierarchy process (AHP): a case study in Qom city, Iran. Environ. Earth Sci, 77. DOI: https://doi.org/10.1007/s12665-017-7215-3

Kilicoglu C, Cetin M, Aricak B, Sevik H, 2020. Site selection by using the multi-criteria technique - a case study of Bafra, Turkey. Environ. Monit. Assess., 192: 1-12. doi: 10.1007/S10661-020-08562-1

Kükrer S, Mutlu E, 2019. Assessment of surface water quality using water quality index and multivariate statistical analyses in Saraydüzü Dam Lake, Turkey. Environ. Monit. Assess. 191. DOI: https://doi.org/10.1007/s10661-019-7197-6

Kutlu B, Mutlu E, 2021. Multivariate statistical evaluation of dissolved trace elements and water quality assessment in the Karaca dam, Turkey. EQA - Int. J. Environ. Qual., 44: 26-31. doi: 10.6092/ISSN.2281-4485/12231

Mutlu E, 2021. Determination of seasonal variations of heavy metals and physicochemical parameters in Kildir Pond (Yildizeli - Sivas). Fresenius Environ. Bull., 30: 5773-5780.

Mutlu E, 2019. Evaluation of spatio-temporal variations in water quality of Zerveli stream (northern Turkey) based on water quality index and multivariate statistical analyses. Environ. Monit. Assess. 191. DOI: https://doi.org/10.1007/s10661019-7473-5

Ottomano PG, Bottalico F, El Bilali H, Cardone G, Capone R, 2021. Food losses and waste in the context of sustainable food and nutrition security, in: Food Security and Nutrition. Elsevier. pp. 235-255. ISBN: 978-0-12-820521-1

Rada EC, Ragazzi M, Fedrizzi P, 2013. Web-GIS oriented systems viability for municipal solid waste selective collection optimization in developed and transient economies. Waste Manag. DOI: https://doi.org/10.1016/ j.wasman.2013.01.002

Randazzo L, Cusumano A, Oliveri G, Di Stefano P, Renda P, Perricone M, Zarcone G, 2018. Landfill site selection for municipal solid waste by using AHP method in GIS environment: Waste management decision-support in sicily (Italy). Detritus, 2: 78-88. doi: 10.31025/2611-4135/ 2018.13656

Saaty TL, 2002. Decision making with the Analytic Hierarchy Process. International Journal of Services Sciences 1: 215229. doi: $10.1504 / \mathrm{ijssci} .2008 .017590$ 
Sadhasivam N, Sheik Mohideen AR, Alankar B, 2020. Optimisation of landfill sites for solid waste disposal in Thiruverumbur taluk of Tiruchirappalli district, India. Environ. Earth Sci. 79: 1-20. doi: 10.1007/s12665-02009264-0

Sliz-Szkliniarz B, Vogt J, 2012. A GIS-based approach for evaluating the potential of biogas production from livestock manure and crops at a regional scale: A case study for the Kujawsko-Pomorskie Voivodeship. Renew. Sustain. Energy Rev. 16: 752-763. doi: 10.1016/j.rser.2011.09.001

Sultana A, Kumar A, 2012. Optimal siting and size of bioenergy facilities using geographic information system. Appl. Energy, 94: 192-201. doi: 10.1016/j.apenergy.2012.01.052

Tüdeş Ş, Kumlu KBY, 2017. Solid Waste Landfill Site Selection in the Sense of Environment Sensitive Sustainable Urbanization: Izmir, Turkey Case, in: IOP Conference Series: Materials Science and Engineering. 245: 082063. doi: $10.1088 / 1757-899 X / 245 / 8 / 082063$

Turkish Statistical Institute, 2021. Data Portal For Statistics Population and Demography. Available from: https://data.tuik.gov.tr/Kategori/GetKategori?p=nufus-vedemografi-109\&dil=1 [Accessed 8 August 2021]
United Nations, 2019. World population prospects 2019. Available from: https://www.un.org/development/desa/publications/ world-population-prospects-2019-highlights.html [Accessed 28 July 2021]

Yalcinkaya S, 2020. A spatial modeling approach for siting, sizing and economic assessment of centralized biogas plants in organic waste management. J. Clean. Prod. 255C: 120040. doi: 10.1016/j.jclepro.2020.120040

Yalcinkaya S, Kirtiloglu OS, 2021. Application of a geographic information system-based fuzzy analytic hierarchy process model to locate potential municipal solid waste incineration plant sites: A case study of Izmir Metropolitan Municipality. Waste Manag. Res. 39: 174-184. doi: 10.1177/ 0734242 X20939636

Yalçınkaya S, 2020. Katı Atık Toplama ve Taşıma Sisteminden Kaynaklanan Hava Kirleticileri Emisyonlarının Mekansal Analiz Teknikleri ile Farklı Araç Kapasiteleri için Hesaplanması: İzmir Çiğli Örneği. Doğal Afetler ve Çevre Derg. 6: 366-376. doi: 10.21324/dacd.675605

Yildirim V, Memisoglu T, Bediroglu S, Colak HE, 2018. Municipal solid waste landfill site selection using multicriteria decision making and gis: Case study of Bursa province. J. Environ. Eng. Landsc. Manag. 26: 107-119. doi: 10.3846/16486897.2017.1364646 